\title{
The Analysis of Wafe Refraction using SWAN Model
}

\author{
Sujantoko ${ }^{1}$
}

\begin{abstract}
Wave simulation is important problem in nearshore coastal design process. Determination of proper wave parameter will provide reliable and accurate design, therefore modeling usually needed to simulate this process where numerical model is the right choice because of its cost is cheaper and the result is quite accurate. SWAN (Simulating Wave Nearshore) is numerical model that already used widely to simulate wave in coastal area. In this research we analyze wave refraction by SWAN model with any coastal profile $(\mathrm{m})$ i.e. $0,01,0,03$ and 0,05 . This simulation also applied in the real problem at Tegal port in Central Java Province. According to the result of this model we find that in the same direction, height, and period, the height of wave break will increase as the coastal slope increase. These problems arise due to decreasing in value of $d_{b} / H_{b}$ that means the peak wave is become steep. Coastal Profile affect the wave height (duo to refraction) about $2 \%-34 \%$. The jetty at Tegal Port induce the wave height big alteration at dock pond $(228,91 \%)$ at wave direction $30^{\circ}$, while at groove, back and head of the jetty, wave reduction reach until $12,96 \% ; 0,02 \%$ and $3,55 \%$ at incoming wave direction $45^{\circ}$. In the head of the jetty, the wave almost doesn't being reduced because diffraction and wave reflection doesn't have significant effect.
\end{abstract}

Keywords - simulation, SWAN, coastal profile, refraction, reduction

\section{PENDAHULUAN}

$\mathrm{U}$ saha rekayasa rekayasa pantai dan lepas pantai seringkali membutuhkan informasi yang detail mengenai kondisi gelombang pada suatu lokasi tertentu. Biasanya informasi ini tidak tersedia karena data pengamatan dilapangan seringkali tidak lengkap karena mahalnya biaya. Hal ini mendorong munculnya beragam model numerik untuk memprediksi gelombang dalam penjalarannya menuju pantai.

Sejarah perkembangan model gelombang dimulai sejak tahun 1947 oleh Svedrup dan Munk (dalam Jin K$\mathrm{R}$ dan Ji Z-G [1]) memperkenalkan formula empirik untuk memperkirakan tinggi gelombang signifikan dilaut dan memperkenalkan konsep tinggi gelombang signifikan selanjutnya model gelombang terus mengalami perkembangan dan semakin beragam. model empirik yang cukup terkenal adalah Revised Shore Protection Manual (RSPM) model yang merupakan hasil pengembangan Hurdle dan Strive (1989) (dalam Andrew [2]) terhadap formula empirik dari Shore Protection Manual (SPM).

Naskah diterima pada tanggal 16 Maret 2009, selesai revisi pada 11 Mei 2009

Sujantoko adalah dosen Jurusan Teknik Kelautan, FTK, Institut Teknologi Sepuluh Nopember, Surabaya, INDONESIA

e-mail : sujantoko@oe.its.ac.id
Beberapa model yang lain dikembangkan berdasarkan persamaan "mild slope" seperti REF/DIF_S, merupakan generasi terbaru REF/DIF_1 yang dikembangkan oleh Kirby dan Dalrymple [3]. Selain persamaan "mild slope" juga berkembang model gelombang yang didasarkan pada persamaan Boussinesq. Banyak peneliti yang telah mengembangkan pendekatan Boussinesq untuk semakin menyempurnakan model gelombang yang didasarkan pada persamaan ini [1].

Pendekatan yang lain adalah berdasarkan persamaan kerapatan energi gelombang. Pendekatan dengan spektrum kerapatan energi gelombang didasarkan pada persamaan Eulerian. Model spektrum ini telah banyak dikembangkan oleh beberapa ahli, dan salah satunya telah dikembangkan untuk memperkirakan tinggi gelombang di perairan dangkal oleh Ewing dan Hogue (1993) dalam Jin K-R dan Ji Z-G [1]. Model spektra ini mampu mempertimbangkan pengaruh refraksi gelombang, pembangkitan gelombang, kehilangan energi gelombang, dan interaksi antar gelombang baik di perairan dalam maupun di perairan dangkal [4]. Meskipun demikian model spektra ini tidak melibatkan pengaruh dari difraksi gelombang. Pengaruh dari difraksi gelombang biasanya dihitung menggunakan model mild-slope [5] atau dengan model Boussinesq [6]. Namun kelemahan dua model yang yang disebutkan terakhir ini adalah tidak bisa digunakan untuk menghitung pembangkitan gelombang, kehilangan energi gelombang, dan interaksi antar gelombang.

Pendekatan dengan spektrum kerapatan energi gelombang telah mengilhami lahirnya model numerik yang mampu memperkirakan tinggi gelombang pada suatu lokasi tertentu berdasarkan data angin, batimetri, dan data lingkungan yang diberikan. Model numeris yang sudah banyak dikenal dan digunakan dalam rekayasa pantai diantaranya adalah SWAN. SWAN adalah akronim dari simulating wave nearshore dan merupakan model gelombang untuk perairan dangkal. Model SWAN dikembangkan pertama kali pada tahun 1970 dan digunakan untuk memperkirakan tinggi gelombang dan spektrum gelombang. Model ini pada awalnya tidak melibatkan perhitungan pengaruh interaksi antar gelombang. Kemudian dalam perkembanganya lahir generasi kedua dari model gelombang ini yang melibatkan pengaruh interaksi antar gelombang. Meskipun generasi kedua model gelombang ini mampu memperbaiki hasil simulasi, namun model ini hanya bisa diterapkan pada daerah dengan kondisi angin tertentu saja. Akhirnya sampai saat ini telah dikembangkan generasi ketiga dari model gelombang ini. Model generasi ketiga ini mampu menyele- 
saikan masalah diatas dengan mengintegrasikan persamaan energi gelombang dalam model [7], [8]. Model generasi ketiga ini mampu memperhitungkan pengaruh refraksi, shoaling, dan blocking sepanjang penjalaran gelombang [1]. Pada awalnya model generasi ketiga ini belum bisa digunakan untuk memperhitungkan pengaruh difraksi gelombang [9], namun sampai saat ini telah dilakukan modifikasi, sehingga pada versi terbaru SWAN cycle III version 40.41 telah dilibatkan perhitungan difraksi dengan menggunakan persamaan "mild slope".

Beberapa peneliti telah melakukan penelitian untuk memeriksa kemampuan dan keakuratan SWAN dalam memodelkan gelombang diperairan dangkal. Hal ini ditunjukkan dengan beberapa hasil verifikasi perhitungan SWAN terhadap pengukuran dilapangan yang dimuat dalam beberapa jurnal. Mai et.al [10] telah membandingkan hasil perhitungan parameter gelombang dengan hasil pengukuran menggunakan "waverider buoy" dan hasil perhitungan menggunakan model gelombang MIKE 21 di pantai utara Frissian, Jerman. Berdasarkan penelitian ini ditunjukkan bahwa SWAN memberikan hasil yang akurat terhadap kedua pembanding tersebut. Silva et.al [11] telah membandingkan parameter gelombang hasil perhitungan menggunakan SWAN dengan hasil pengukuran menggunakan "ACDP sensor buoy" diperairan pantai barat Portugal, disebelah utara pelabuhan Shines. Hasilnya menunjukkan kesesuaian dan tingkat perbedaan yang bisa diterima. Dykes et.al [12] menunjukkan bahwa model gelombang HISWA merupakan "steady state model" sedangkan SWAN bisa steady state maupun time dependent. Kemudian Sujantoko et al [13] telah menguji kemampuan dan keakuratan model SWAN dengan berbagai hasil laboraturium, yakni percobaan Johnson tahun 1952, Cox et.al tahun 1991, Briggs et.al tahun 1991, Beji dan Battjes tahun 1993, dan Percobaan Yu et.al tahun 1998. Peneliti lain yang telah menggunakan SWAN diantaranya: Gorman dan Nielson [14], Chen dan Douglas [15], Schoones dan Luger [16], Parks et.al [17], Edge [18] dan lain-lain.

Menyadari kenyataan penggunaan SWAN yang begitu luas dan sangat bermanfaat dalam dunia rekayasa pantai maka model ini selayaknya dikuasai oleh pemerhati bidang tersebut. Pada penelitian ini penulis ingin melakukan studi refraksi gelombang dengan model SWAN diberbagai kondisi kemiringan pantai yang berbeda dan kondisi riil di pelabuhan Tegal, setelah sebelumnya melakukan validasi [13].

\section{DESKRIPSI MODEL SWAN}

SWAN menggambarkan evolusi gelombang di daerah pantai dengan input angin, dissipasi energi, interaksi antar gelombang dan perubahan parameter gelombang $(\mathrm{H}, \mathrm{T}, \alpha)$ karena variasi kedalaman air dan pengaruh arus. Perubahan spektrum kerapatan aksi gelombang ini dinyatakan dalam persamaan ketimbangan aksi gelombang yang dalam koordinat kartesian (Hasselman et al, 1973 dalam Booij et al [4]) dapat ditulis sebagai berikut:

$$
\frac{\partial N}{\partial t}+\frac{\partial}{\partial x} C_{x} N+\frac{\partial}{\partial y} C_{y} N+\frac{\partial}{\partial \sigma} C_{\sigma} N+\frac{\partial}{\partial \theta} C_{\theta} N=\frac{S}{\sigma}
$$

Dimana $\mathrm{N}=\mathrm{N}(\mathrm{t}, \mathrm{x}, \mathrm{y}, \sigma, \theta)$ adalah spektrum kerapatan aksi gelombang; $t$ waktu; $\mathrm{C}_{\mathrm{x}}$ dan $\mathrm{C}_{\mathrm{y}}$ kecepatan penjalaran gelombang dalam arah $\mathrm{x}$ dan $\mathrm{y} ; \mathrm{C}_{\sigma}$ dan $\mathrm{C}_{\theta}$ adalah kecepatan penjalaran gelombang dalam ruang $\sigma$ dan $\theta ; \sigma$ frekuensi relatif; $\theta$ arah gelombang; $S=S$ total $(\sigma, \theta)$ adalah suku source dari spektral kerapatan energi gelombang. Suku pertama mewakili perubahan rata-rata waktu kerapatan, suku kedua dan ketiga mewakili penjalaran kerapatan aksi dalam ruang. Suku keempat mewakili frekuensi relatif akibat variasi kedalaman air dan arus dan suku kelima mewakili refraksi gelombang. Suku keenam mewakili kombinasi input angin, efek disipasi gelombang, dan interaksi gelombang non-linear.

Prinsip dasar perhitungan model SWAN adalah mengintegrasikan persamaan kesetimbangan aksi gelombang dengan menggunakan metode selisih hingga (finite difference method) terhadap 5 variabel yang terkait. Variabel waktu didiskristisasi dengan simple time step $\Delta \mathrm{t}$ untuk proses integrasi. Variabel ruang horizontal didiskritisasi dengan grid rectangular $\Delta \mathrm{x}$ dan $\Delta \mathrm{y}$, sedangkan variabel spektrum dalam model didiskritisasi dengan constant directional resolution $\Delta \theta$ dan dengan constant relative frequency resolution $\Delta \sigma / \sigma$. Skema numerik yang dipilih dalam SWAN didasarkan pada kestabilan, keakuratan dan efisiensi waktu perhitungan [8]. Skema yang dipilih adalah implicit upwind. Pada skema ini variable waktu dan ruang tidak saling tergantung satu dengan lainnya.

Kondisi batas dan SWAN baik dalam batas geografis maupun spektral, keduanya akan menyerap energi gelombang yang menjalar ke daerah batas ini. Kondisi batas yang berupa daratan bisa langsung menyerap energi gelombang dan tidak memerlukan informasi kondisi gelombang lagi, karena secara keseluruhan energi terserap. Namun untuk daerah yang terbuka yang berupa perairan, informasi gelombang yang lengkap akan membantu memberikan hasil perhitungan yang akurat. Jika informasi gelombang didaerah ini tidak lengkap atau tidak ada sama sekali, maka sebaiknya daerah batas ini diletakan pada daerah yang cukup jauh dari daerah perhitungan.

\section{MODEL REFRAKSI GELOMBANG DENGAN SWAN}

Model numerik pada SWAN menggunakan koordinat kartesian, dimensi ruang didiskritisasi dengan grid segiempat (rectangular) $\Delta \mathrm{x}$ dan $\Delta \mathrm{y}$. Sensitivitas hasil model diuji dengan frekuensi penjalaran gelombang tunggal dari perairan dalam menuju dangkal. Untuk maksud ini simulasi numerik refraksi gelombang menggunakan skenario model dengan berbagai kemiringan pantai. Model 1, 2 dan 3 dengan kemiringan 0,$01 ; 0,03$ dan 0,05 secara berturut-turut (Gambar 1). Sedangkan parameter gelombang, seperti periode, tinggi dan arah gelombang datang seperti ditunjukkan pada Tabel 1. Kedalaman perairan $\mathrm{d}=30 \mathrm{~m}$, jarak ujung slope ke perairan dalam $\mathrm{x}=500 \mathrm{~m}$, sedangkan jarak dari perairan dalam ke garis pantai adalah $1100 \mathrm{~m}, 1500 \mathrm{~m}$ dan $3500 \mathrm{~m}$.

Dimana $a_{1}$ menunjukkan data tinggi gelombang, $\mathrm{H}$ $=1 \mathrm{~m}$ dan periode gelombang, $\mathrm{T}=5$ detik pada arah gelombang datang $0^{\circ}$. Simbul yang lain menujukkan keterangan yang sejenis. 



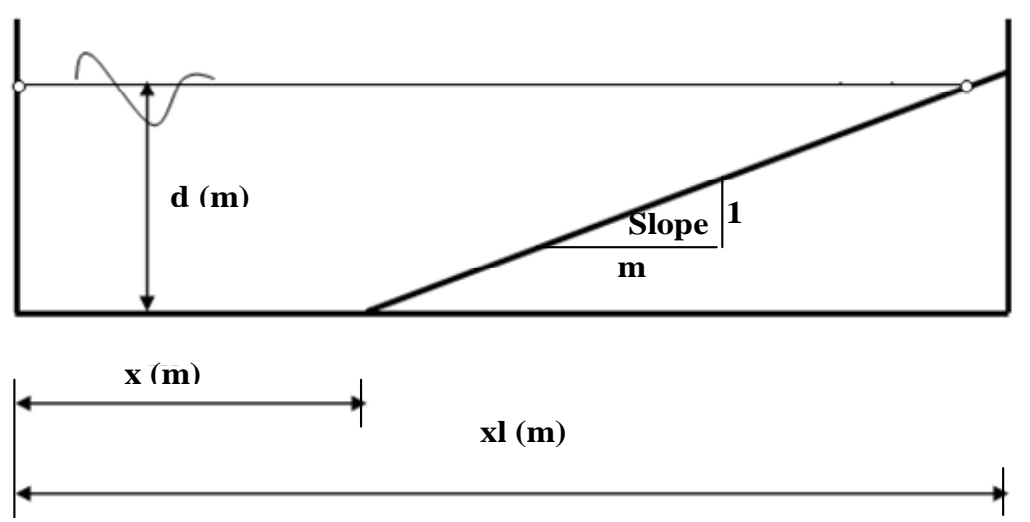

Gambar 1. Konfigurasi kemiringan dalam skenario pemodelan

TABEL 1

SKENARIO MODEL SWAN PADA BERBAGAI TINGGI, PERIODE DAN SUDUT GELOMBANG DATANG

\begin{tabular}{|c|c|c|c|c|c|c|c|c|c|c|c|c|c|c|c|}
\hline \multirow{3}{*}{$\begin{array}{l}\text { Parameter } \\
\text { Gelombang }\end{array}$} & \multicolumn{15}{|c|}{ Arah Gelombang Datang } \\
\hline & \multicolumn{5}{|c|}{$\mathrm{a}=0^{\circ}$} & \multicolumn{5}{|c|}{$\mathrm{a}=30^{\circ}$} & \multicolumn{5}{|c|}{$\mathrm{a}=45^{\circ}$} \\
\hline & al & b1 & $\mathrm{c} 1$ & $\mathrm{~d} 1$ & e1 & a2 & b2 & c2 & $\mathrm{d} 2$ & e2 & a3 & b3 & $\mathrm{c} 3$ & $\mathrm{~d} 3$ & e3 \\
\hline $\mathrm{H}(\mathrm{m})$ & 1 & 2 & 3 & 4 & 5 & 1 & 2 & 3 & 4 & 5 & 1 & 2 & 3 & 4 & 5 \\
\hline $\mathrm{T}(\mathrm{det})$ & 5 & 8 & 10 & 13 & 15 & 5 & 8 & 10 & 13 & 15 & 5 & 8 & 10 & 13 & 15 \\
\hline
\end{tabular}

Simulasi SWAN di berbagau kemiringan pantai.

Ukuran grid kearah $\mathrm{x}$ dan y untuk pemodelan berbagai kemiringan 0,$01 ; 0,03$ dan 0,05 ditentukan seragam, $\Delta \mathrm{x}$ $=\Delta \mathrm{y}=50$. SWAN digunakan untuk menentukan posisi gelombang pecah akibat refraksi gelombang pada 15 kondisi variasi parameter gelombang (Tabel 1). Posisi gelombang pecah dianalisa dengan menggunakan wave steepness yang dihasilkan, dimana nilai wave steepness yang terbesar sepanjang daerah perhitungan menunjukkan posisi gelombang pecah.

Berdasarkan hasil pemodelan, tinggi gelombang dalam penjalarannya menuju pantai akan mengalami perubahan akibat perubahan kedalaman perairan. Pada pantai dengan kemiringan 0,01 (Model 1), semakin tinggi sudut gelombang datang, tinggi gelombang akan mengalami penurunan tetapi letak gelombang pecah relatif sama (Gambar 2 - 4). Sebagai contoh Model $1 a_{1}$ dengan Model $1 \mathrm{a}_{2}$ yang memiliki tinggi gelombang datang $1 \mathrm{~m}$ dan periode 5 detik, gelombang pecah terjadi pada posisi \pm $110 \mathrm{~m}$ dari garis pantai pada kedalaman $1,1 \mathrm{~m}$ dengan tinggi gelombang pecah $0,93 \mathrm{~m}$ dan $0,89 \mathrm{~m}$. Rata-rata perubahan tinggi gelombang tersebut $12,2 \% ; 1,2 \%$ dan $18,8 \%$ pada arah gelombang datang $0^{\circ}, 30^{\circ}$ dan $45^{\circ}$ secara berturut-turut (Tabel 2). Tinggi gelombang pecah jika dibandingkan dengan arah gelombang datang $0^{\circ}$ pada tinggi dan periode gelombang yang juga mengalami penurunan sebesar 3,15\% - 4,49\% untuk arah gelombang datang $30^{\circ}$ dan $9,85 \%-12,8 \%$ arah gelombang datang $45^{\circ}$. Pada Model 2 tinggi gelombang mengalami rata-rata perubahan sebesar $15,6 \% ; 4 \%$ dan $-20,6 \%$ pada arah $0^{\circ}$, $30^{\circ}$ dan $45^{\circ}$ secara berturut-turut (Tabel 3) dengan reduksi sebesar 3,3\%-3,7\% pada arah $30^{\circ}$ dan $11,9 \%-13 \%$ pada arah gelombang datang $45^{\circ}$ jika dibandingkan dengan arah gelombang datang $0^{\circ}$. Demikian juga pada Model 3 tinggi gelombang mengalami perubahan rata-rata $15 \%$, $2,8 \%,-15,6 \%$ pada arah $0^{\circ}, 30^{\circ}$ dan $45^{\circ}$ secara berturutturut (Tabel 4) dengan reduksi gelombang sebesar $3,69 \%-4,4 \%$ pada arah $30^{\circ}$ dan $10,1 \%-11 \%$ pada arah gelombang datang $45^{\circ}$ jika dibandingkan dengan arah gelombang datang $0^{\circ}$.

Analisa perubahan tinggi gelombang (akibat refraksi) juga dilakukan dengan melihat hubungan wave steepness, $\mathrm{H}_{\mathrm{b}} / \mathrm{gT}^{2}$ dengan kedalaman dan tinggi gelombang pecah, $d_{b} / H_{b}($ Gambar 5 - 7). Berdasarkan hasil model tersebut dapat disimpulkan bahwa pada tinggi, periode dan arah gelombang yang sama, maka gelombang pecah akan semakin besar seiring dengan bertambahnya kemiringan suatu perairan. Hasil model ini jika dibandingkan dengan penelitian yang dilakukan oleh CERC [19] mempunyai nilai yang hampir sama. Hal ini nampak dengan jelas kecenderungan bentuk dan pola garis yang sama. 


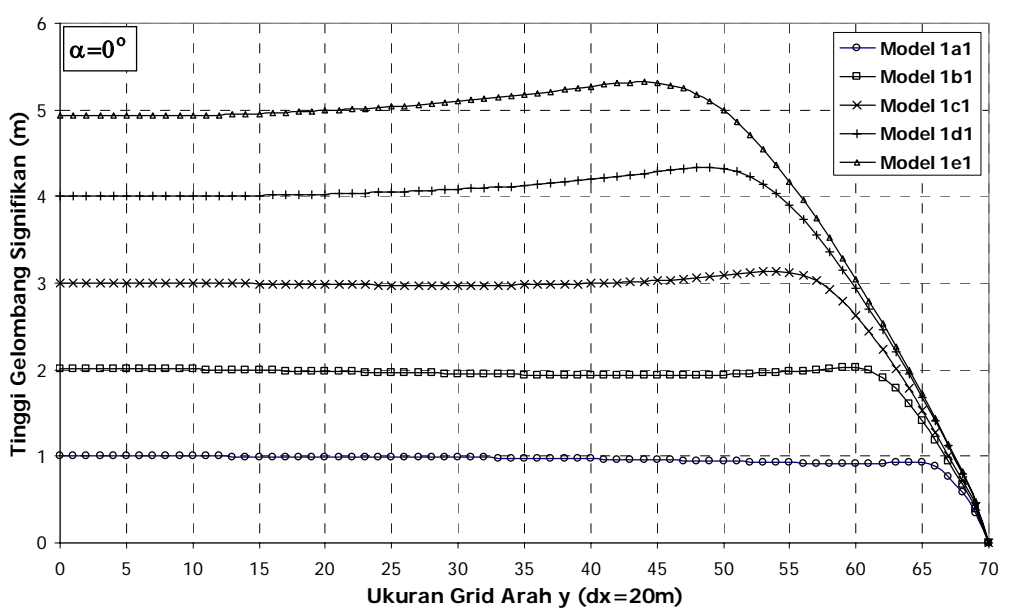

Gambar 2. Perubahan tinggi gelombang Model 1 untuk arah gelombang datang $0^{\circ}$

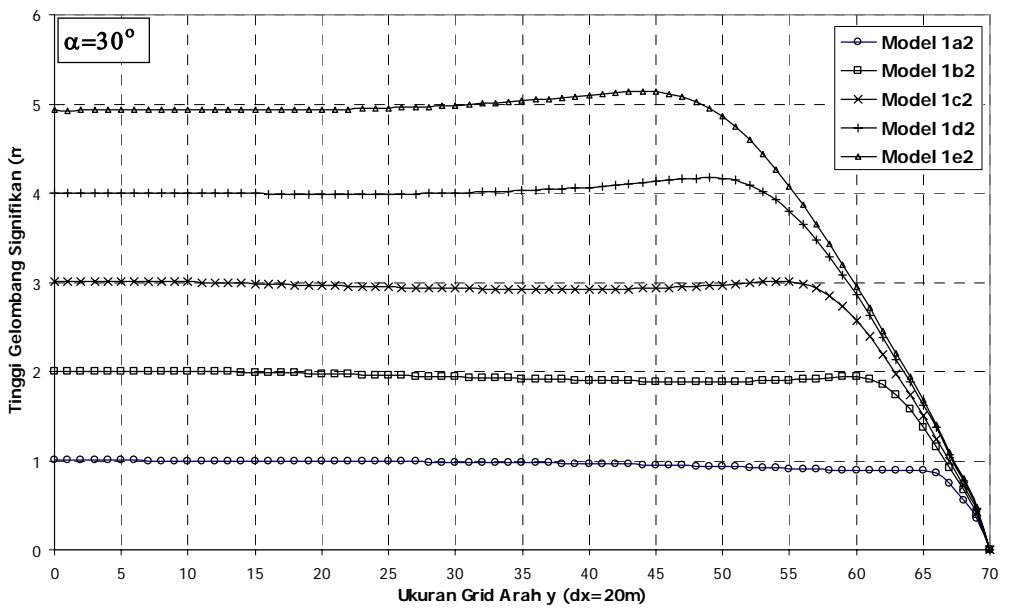

Gambar 3. Perubahan tinggi gelombang Model 1 untuk arah gelombang datang $30^{\circ}$

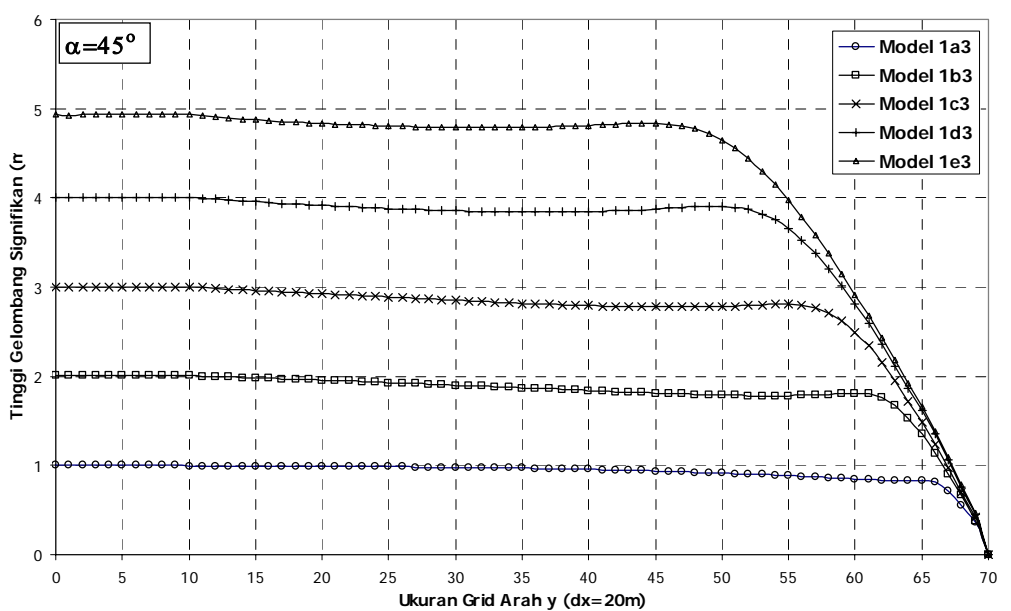

Gambar 4. Perubahan tinggi gelombang Model 1 untuk arah gelombang datang $45^{\circ}$ 
TABEL 2

PERUBAHAN DAN LETAK TINGGI GELOMBANG PECAH PADA MODEL 1

\begin{tabular}{|c|c|c|c|c|c|c|c|c|c|c|c|c|c|c|c|}
\hline \multirow{3}{*}{$\begin{array}{c}\text { Parameter } \\
\text { Gelombang }\end{array}$} & \multicolumn{15}{|c|}{ Model 1 dengan $\mathrm{m}=0,01$} \\
\hline & \multicolumn{5}{|c|}{$\alpha=0^{\circ}$} & \multicolumn{5}{|c|}{$\alpha=30^{\circ}$} & \multicolumn{5}{|c|}{$\alpha=45^{\circ}$} \\
\hline & a1 & b1 & $\mathrm{c} 1$ & d1 & e1 & a2 & b2 & $\mathrm{c} 2$ & $\mathrm{~d} 2$ & $\mathrm{e} 2$ & a3 & b3 & c3 & d3 & e3 \\
\hline Ho (m) & 1 & 2 & 3 & 4 & 5 & 1 & 2 & 3 & 4 & 5 & 1 & 2 & 3 & 4 & 5 \\
\hline $\mathrm{Hb}(\mathrm{m})$ & 0.93 & 2.02 & 3.13 & 4.29 & 5.24 & 0.89 & 1.94 & 3.01 & 4.14 & 5.08 & 0.84 & 1.79 & 2.79 & 3.87 & 4.77 \\
\hline $\mathrm{db}(\mathrm{m})$ & 1.13 & 2.43 & 3.76 & 5.12 & 6.26 & 1.08 & 2.33 & 3.61 & 4.94 & 6.06 & 1.01 & 2.16 & 3.36 & 4.61 & 5.68 \\
\hline $\mathrm{Xb}(\mathrm{m})$ & 113 & 243 & 376 & 512 & 626 & 108 & 233 & 361 & 494 & 606 & 101 & 216 & 336 & 461 & 568 \\
\hline $\begin{array}{l}\text { Perubahan } \mathrm{H} \\
(\mathrm{o} / \mathrm{o})\end{array}$ & -7 & 2 & 13 & 29 & 24 & -11 & -6 & 1 & 14 & 8 & -16 & -21 & -21 & -13 & -23 \\
\hline rata-rata $(\mathrm{o} / \mathrm{o})$ & \multicolumn{5}{|c|}{12.2} & \multicolumn{5}{|c|}{1.2} & \multicolumn{5}{|c|}{-18.8} \\
\hline \multicolumn{6}{|c|}{$\begin{array}{c}\text { Reduksi tinggi gelombang pecah }(\mathrm{Hb}) \text { terhadap } \alpha= \\
0^{\circ} \text { untuk Ho dan T yang sama }(\mathrm{o} / \mathrm{o})\end{array}$} & 4.49 & 4.12 & 3.99 & 3.62 & 3.15 & 10.7 & 12.8 & 12.2 & 10.9 & 9.85 \\
\hline
\end{tabular}

TABEL 3

PERUBAHAN DAN LETAK TINGGI GELOMBANG PECAH PADA MODEL 2

\begin{tabular}{|c|c|c|c|c|c|c|c|c|c|c|c|c|c|c|c|}
\hline \multirow{3}{*}{$\begin{array}{l}\text { Parameter } \\
\text { Gelombang }\end{array}$} & \multicolumn{15}{|c|}{ Model 2 dengan $\mathrm{m}=0,03$} \\
\hline & \multicolumn{5}{|c|}{$\alpha=0^{\circ}$} & \multicolumn{5}{|c|}{$\alpha=30^{\circ}$} & \multicolumn{5}{|c|}{$\alpha=45^{\circ}$} \\
\hline & a1 & b1 & $\mathrm{c} 1$ & d1 & $\mathrm{e} 1$ & $\mathrm{a} 2$ & $\mathrm{~b} 2$ & $\mathrm{c} 2$ & $\mathrm{~d} 2$ & $\mathrm{e} 2$ & $\mathrm{a} 3$ & b3 & $\mathrm{c} 3$ & $\mathrm{~d} 3$ & e3 \\
\hline Ho (m) & 1 & 2 & 3 & 4 & 5 & 1 & 2 & 3 & 4 & 5 & 1 & 2 & 3 & 4 & 5 \\
\hline $\mathrm{Hb}(\mathrm{m})$ & 0.94 & 2.02 & 3.16 & 4.34 & 5.32 & 0.91 & 1.94 & 3.03 & 4.19 & 5.13 & 0.84 & 1.81 & 2.78 & 3.83 & 4.71 \\
\hline $\mathrm{db}(\mathrm{m})$ & 1.01 & 2.15 & 3.35 & 4.57 & 5.56 & 0.97 & 2.06 & 3.21 & 4.39 & 5.36 & 0.9 & 1.91 & 2.94 & 4 & 4.89 \\
\hline $\mathrm{Xb}(\mathrm{m})$ & 33.7 & 71.7 & 112 & 152 & 185 & 32.4 & 68.7 & 107 & 146 & 179 & 30 & 63.7 & 98.1 & 133 & 163 \\
\hline $\begin{array}{l}\text { Perubahan } \mathrm{H} \\
(\mathrm{o} / \mathrm{o})\end{array}$ & -6 & 2 & 16 & 34 & 32 & -9 & -6 & 3 & 19 & 13 & -16 & -19 & -22 & -17 & -29 \\
\hline $\begin{array}{l}\text { Perubahan } \mathrm{H} \\
\text { rata-rata }(\mathrm{o} / \mathrm{o})\end{array}$ & \multicolumn{5}{|c|}{15.6} & \multicolumn{5}{|c|}{4} & \multicolumn{5}{|c|}{-20.6} \\
\hline $\begin{array}{r}\text { Reduksi tingg } \\
0^{\circ} \text { unt }\end{array}$ & $\begin{array}{l}\text { lomb } \\
\text { Ho da }\end{array}$ & $\begin{array}{l}\text { g pec } \\
\text { T yan }\end{array}$ & $\begin{array}{l}(\mathrm{Hb}) \\
\text { sama }\end{array}$ & $\begin{array}{l}\text { erhad } \\
\mathrm{o} / \mathrm{o})\end{array}$ & $\alpha=$ & 3.3 & 4.12 & 4.29 & 3.58 & 3.7 & 11.9 & 11.6 & 1307 & 13.3 & 13 \\
\hline
\end{tabular}

TABEL 4

PERUBAHAN DAN LETAK TINGGI GELOMBANG PECAH PADA MODEL 3

\begin{tabular}{|c|c|c|c|c|c|c|c|c|c|c|c|c|c|c|c|}
\hline \multirow{3}{*}{$\begin{array}{l}\text { Parameter } \\
\text { Gelombang }\end{array}$} & \multicolumn{15}{|c|}{ Model 2 dengan $\mathrm{m}=0,05$} \\
\hline & \multicolumn{5}{|c|}{$\alpha=0^{\circ}$} & \multicolumn{5}{|c|}{$\mathrm{A}=30^{\circ}$} & \multicolumn{5}{|c|}{$\alpha=45^{\circ}$} \\
\hline & al & b1 & $\mathrm{cl}$ & $\mathrm{d} 1$ & $\mathrm{e} 1$ & a2 & $\mathrm{b} 2$ & $\mathrm{c} 2$ & $\mathrm{~d} 2$ & $\mathrm{e} 2$ & a3 & b3 & c3 & $\mathrm{d} 3$ & e3 \\
\hline Ho (m) & 1 & 2 & 3 & 4 & 5 & 1 & 2 & 3 & 4 & 5 & 1 & 2 & 3 & 4 & 5 \\
\hline $\mathrm{Hb}(\mathrm{m})$ & 0.95 & 2.04 & 3.16 & 4.26 & 5.34 & 0.91 & 1.95 & 3.03 & 4.1 & 5.15 & 0.85 & 1.82 & 2.83 & 3.87 & 4.85 \\
\hline $\mathrm{db}(\mathrm{m})$ & 0.92 & 1.95 & 3.02 & 4 & 5 & 0.88 & 1.86 & 2.89 & 3.85 & 4.81 & 0.81 & 1.72 & 2.68 & 3.62 & 4.52 \\
\hline $\mathrm{Xb}(\mathrm{m})$ & 18.4 & 39 & 60.4 & 80 & 100 & 17.6 & 37.2 & 57.8 & 77 & 96.2 & 16.2 & 34.4 & 53.6 & 72.4 & 90.4 \\
\hline $\begin{array}{l}\text { Perubahan } \mathrm{H} \\
(\mathrm{o} / \mathrm{o})\end{array}$ & -5 & 4 & 16 & 26 & 34 & -9 & -5 & 3 & 10 & 15 & -15 & -18 & -17 & -13 & -15 \\
\hline $\begin{array}{l}\text { Perubahan } \mathrm{H} \\
\text { rata-rata }(\mathrm{o} / \mathrm{o})\end{array}$ & & & 15 & & & & & 2.8 & & & & & -15.6 & & \\
\hline $\begin{array}{r}\text { Reduksi tinggi } \\
0^{\circ} \text { unt }\end{array}$ & $\begin{array}{l}\text { lomb } \\
\text { Ho da }\end{array}$ & $\begin{array}{l}\text { pe } \\
\Gamma \text { ya }\end{array}$ & $\begin{array}{l}(\mathrm{Hb}) \\
\text { sama }\end{array}$ & $\begin{array}{l}\text { arhad } \\
\text { /o) }\end{array}$ & $\alpha=$ & 4.4 & 4.62 & 4.29 & 3.9 & 3.69 & 11.8 & 12.1 & 11.7 & 10.1 & 10.1 \\
\hline
\end{tabular}




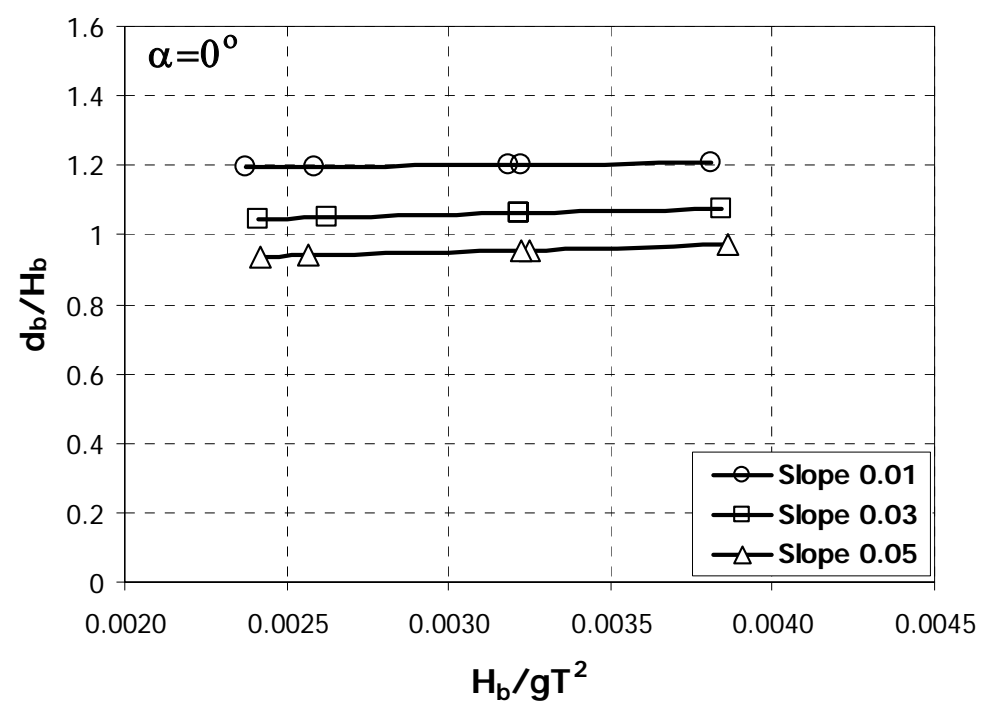

Gambar 5. Hubungan $\mathrm{d}_{\mathrm{b}} / \mathrm{H}_{\mathrm{b}}$ dengan $\mathrm{H}_{\mathrm{b}} / \mathrm{gT}^{2}$ untuk arah gelombang datang $0^{\circ}$

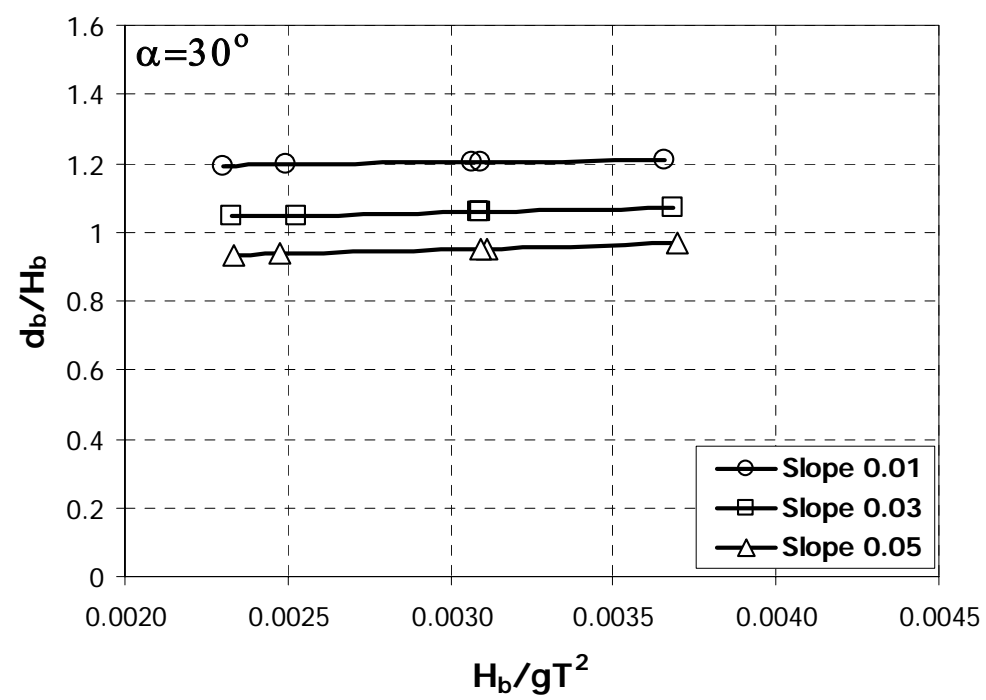

Gambar 6. Hubungan $\mathrm{d}_{\mathrm{b}} / \mathrm{H}_{\mathrm{b}}$ dengan $\mathrm{H}_{\mathrm{b}} / \mathrm{gT}^{2}$ untuk arah gelombang datang $30^{\circ}$

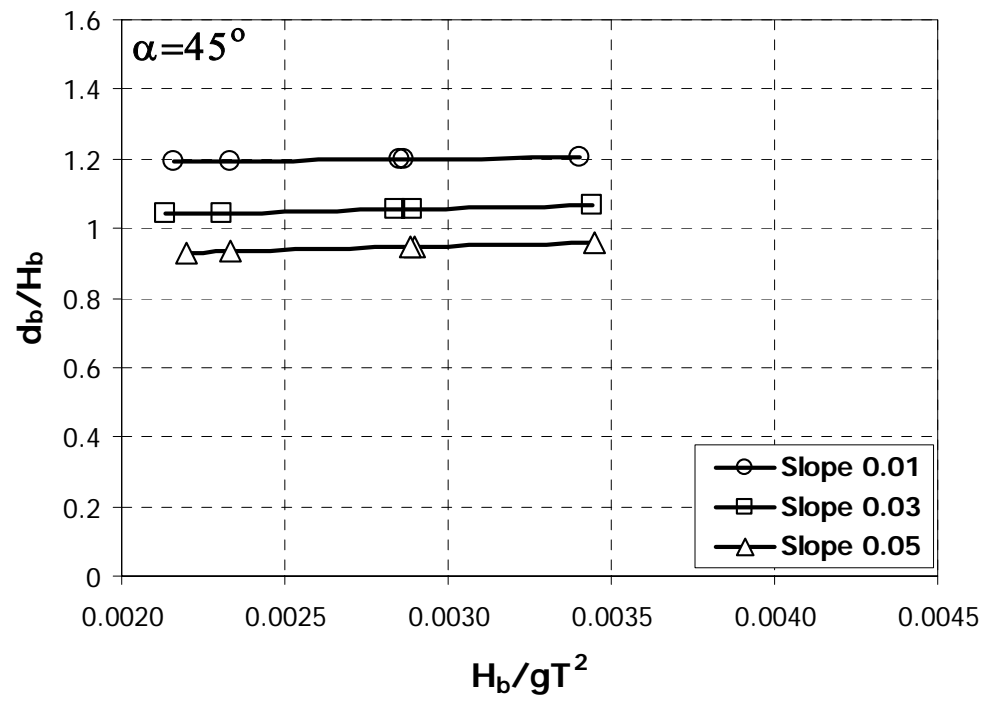

Gambar 7. Hubungan $\mathrm{d}_{\mathrm{b}} / \mathrm{H}_{\mathrm{b}}$ dengan $\mathrm{H}_{\mathrm{b}} / \mathrm{gT}^{2}$ untuk arah gelombang datang $45^{\circ}$

Simulasi SWAN di pelabuhan Tegal. Simulasi dengan model SWAN pada perairan di Indonesia sebagai contoh studi dilakukan di pelabuhan Tegal Jawa Tengah. Pada pelabuhan ini terdapat jetty memanjang dari garis pantai ke tengah laut sepanjang $470 \mathrm{~m}$. Data peta kolam labuh dan alur diperoleh dari hasil sounding PELINDO III 14 Juli 2006 dan peta Lingkungan Pantai Indonesia (LPI) tahun 1998. Ukuran daerah perhitungan untuk pe- 
modelan adalah $2000 \mathrm{~m} \times 2000 \mathrm{~m}$ yang dibagi dalam grid kearah $\mathrm{x}$ dan y sebesar 100, sehingga jarak antar grid adalah $20 \mathrm{~m}$ (Gambar 8). Berdasarkan prediksi dari data angin didapat Tinggi gelombang signifikan, $\mathrm{Hs}=2,4 \mathrm{~m}$ dengan periode gelombang, $\mathrm{T}=7$ detik.

Model SWAN digunakan untuk analisa perubahan penjalaran tinggi gelombang sebelum dan sesudah ada- nya bangunan jetty pada lokasi di alur (grid $\mathrm{i}=43$ ), di depan jetty (grid $\mathrm{j}=62$ ), di belakang jetty (grid $\mathrm{j}=51$ ), dan di kolam labuh (grid $\mathrm{j}=21$ ), seperti ditunjukkan pada Gambar 9. Dari dua kondisi sebelum dan sesudah adanya jetty tersebut akan dilakukan perhitungan nilai perubahan rata-rata tinggi gelombang signifikan dan perubahan arah gelombang untuk tiap arah gelombang datang.

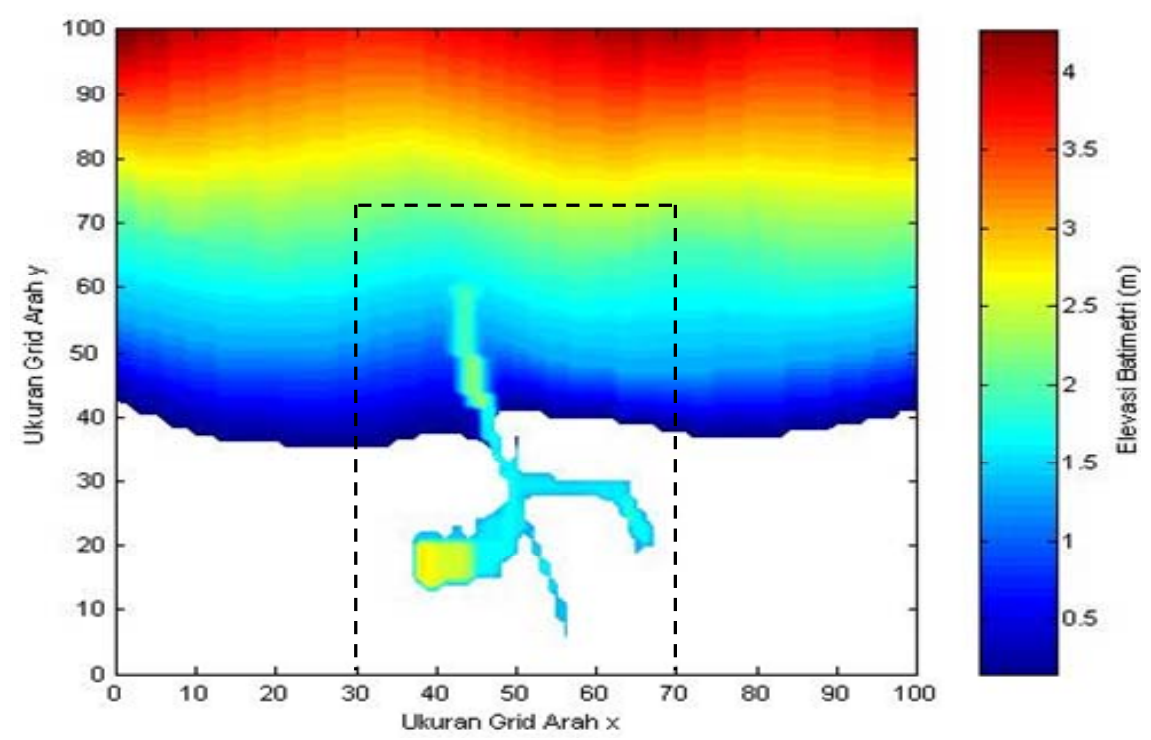

Gambar 8. Domain komputasi untuk simulasi di pelabuhan Legal

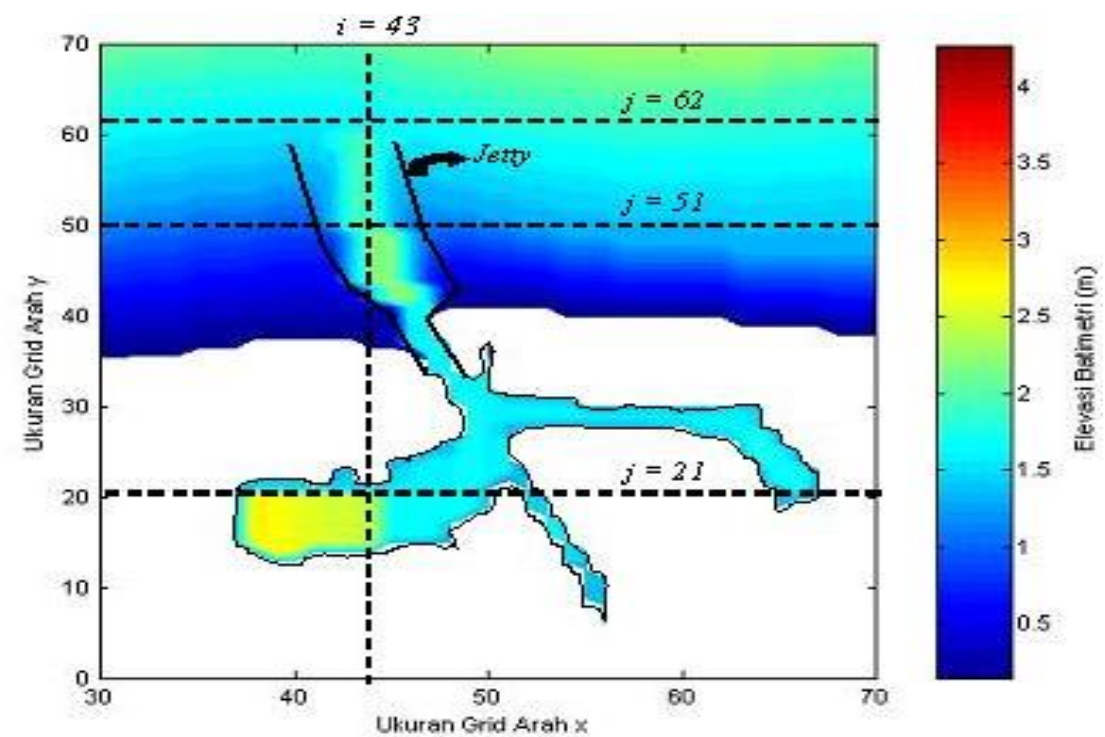

Gambar 9. Lokasi analisa pengaruh jetty terhadap parameter gelombang

Berdasarkan hasil model SWAN, untuk arah gelombang datang $0^{\circ}$ setelah ada jetty tinggi gelombang pada grid ke 50-60 mulai naik karena dampak dari difraksi gelombang yang menghantam pada dinding jetty sehingga menimbulkan energi gelombang, kemudian turun secara drastis (Gambar 10). Sebaliknya pada arah gelombang $30^{\circ}$ dan $45^{\circ}$ tinggi mengalami penurunan setelah adanya jetty (Gambar 11 dan Gambar 12). Perubahan rata-rata tinggi gelombang di daerah alur pelabuhan adalah 2,64\% ; $10,53 \%$ dan $12,96 \%$ untuk arah gelombang $0^{\circ}, 30^{\circ}$ dan $45^{\circ}$ secara berturut-turut. 


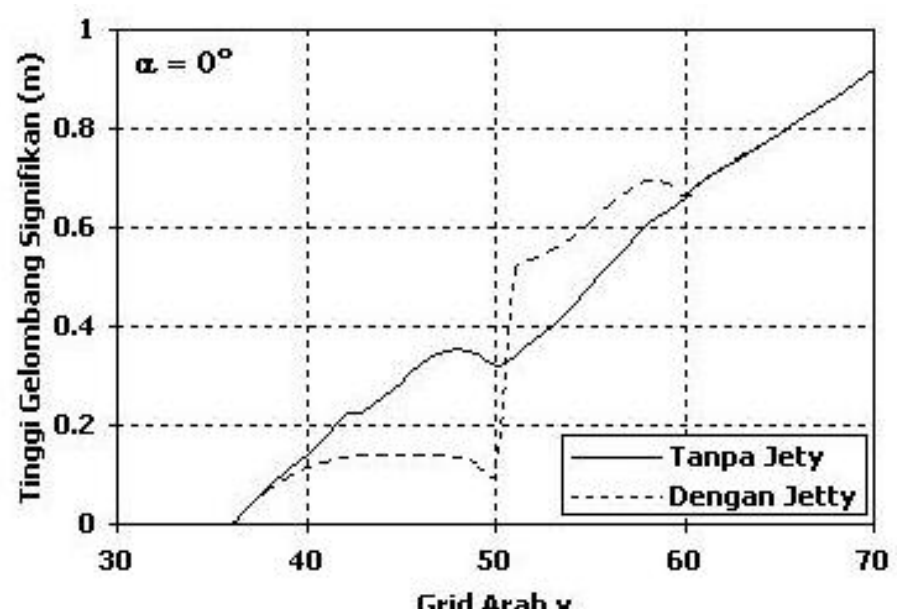

Gambar 10. Perubahan tinggi gelombang di alur pelabuhan Tegal pada $\alpha=0^{\circ}$

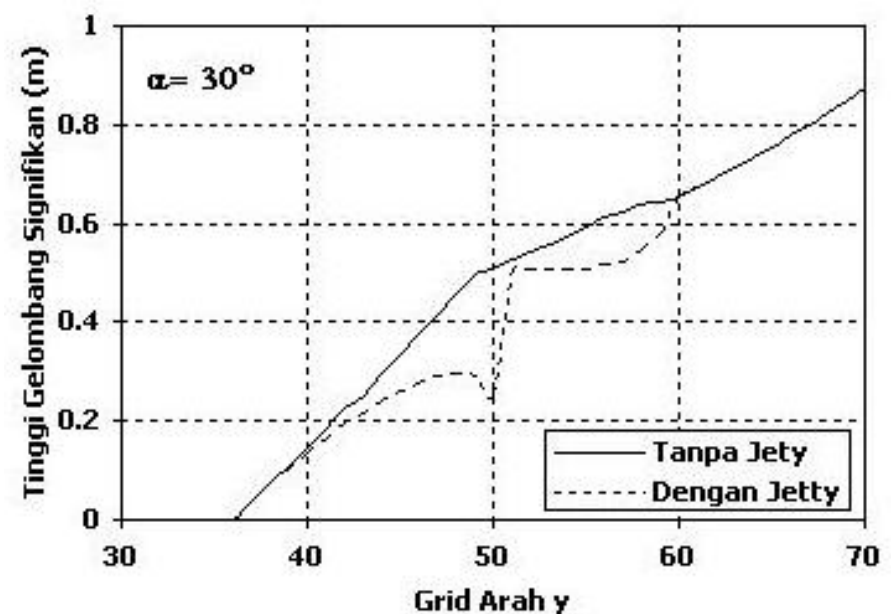

Gambar 11. Perubahan tinggi gelombang di alur pelabuhan Tegal pada $\alpha=30^{\circ}$

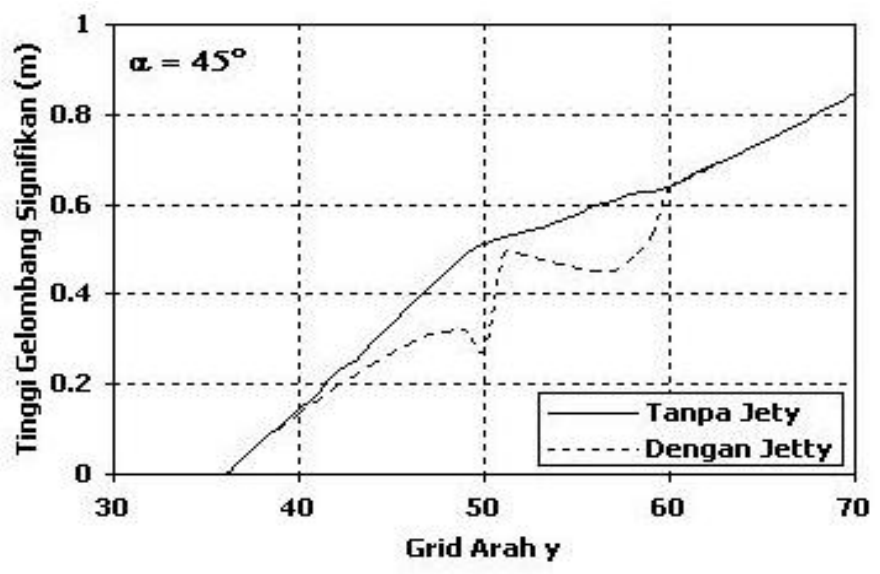

Gambar 12. Perubahan tinggi gelombang di alur pelabuhan Tegal pada $\alpha=45^{\circ}$

Pada lokasi didepan jetty (grid $\mathrm{j}=62$ ) tinggi gelombang hampir tidak mengalami perubahan $(0,02 \%)$ baik pada arah gelombang $0^{\circ}, 30^{\circ}$ dan $45^{\circ}$. Karena gelombang mengalami reduksi di sebelah kiri dan kanan jetty dan dampak gelombang pantul tidak terasa pada lokasi sekitar $70 \mathrm{~m}$ di depan jetty (Gambar 13-15). Pada posisi di belakang jetty (grid $\mathrm{j}=51$ ) yakni alur pelabuhan, gelombang mengalami kenaikan akibat difraksi gelombang dikedua dinding jetty. Disebelah kiri jetty gelombang tertahan oleh jetty sedangkan dikanan jetty tinggi gelombang naik sebelum berimpit karena dampak dari gelombang pantul. Perubahan rata-rata tinggi gelombang pada kon- disi ini adalah sebesar $1,12 \% ; 0,18 \%$ dan $3,55 \%$ untuk arah gelombang datang $0^{\circ}, 30^{\circ}$ dan $45^{\circ}$ (Gambar 16-18). Analisa perubahan tinggi gelombang di daerah kolam pelabuhan (grid $\mathrm{j}=21$ ) secara kesuluruhan gelombang mengalami penurunan yang sangat tajam akibat adanya jetty walaupun tinggi gelombang di kolam labuh sangat kecil (0-0,014 m). Penurunan ini disebabkan karena ruang gerak air di pelabuhan semakin sempit dan jaraknya cukup jauh dari muara pelabuhan $(800 \mathrm{~m})$. Perubahan rata-rata tinggi gelombang dikolam labuh adalah $63,03 \%$ ; 228,91\% dan 227,17\% pada arah gelombang $0^{\circ}, 30^{\circ}$ dan $45^{\circ}$. (Gambar 19-21). 


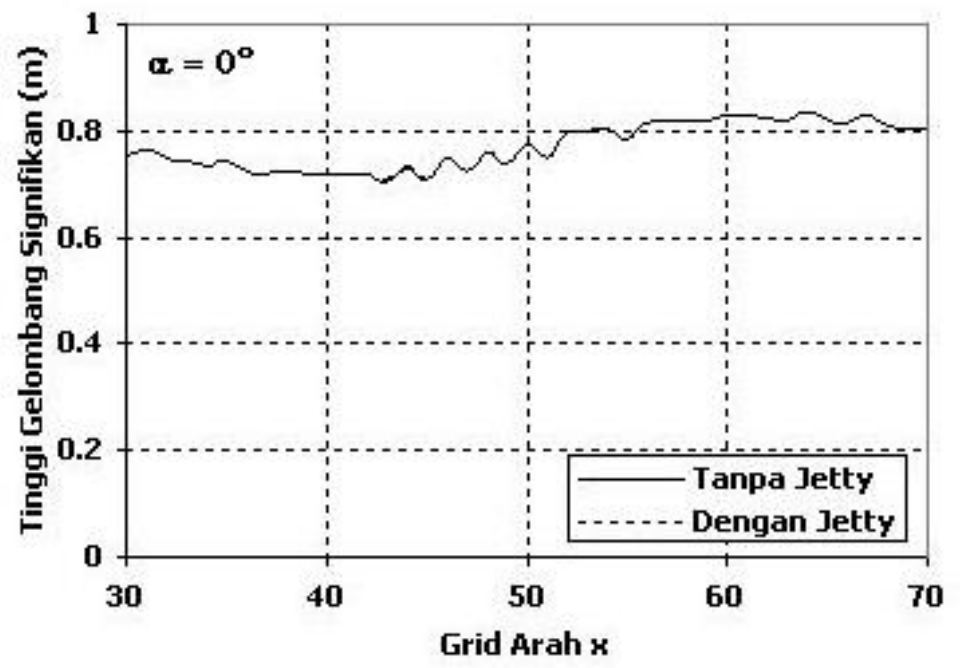

Gambar 13. Perubahan tinggi gelombang di depan jetty pada $\alpha=0^{\circ}$

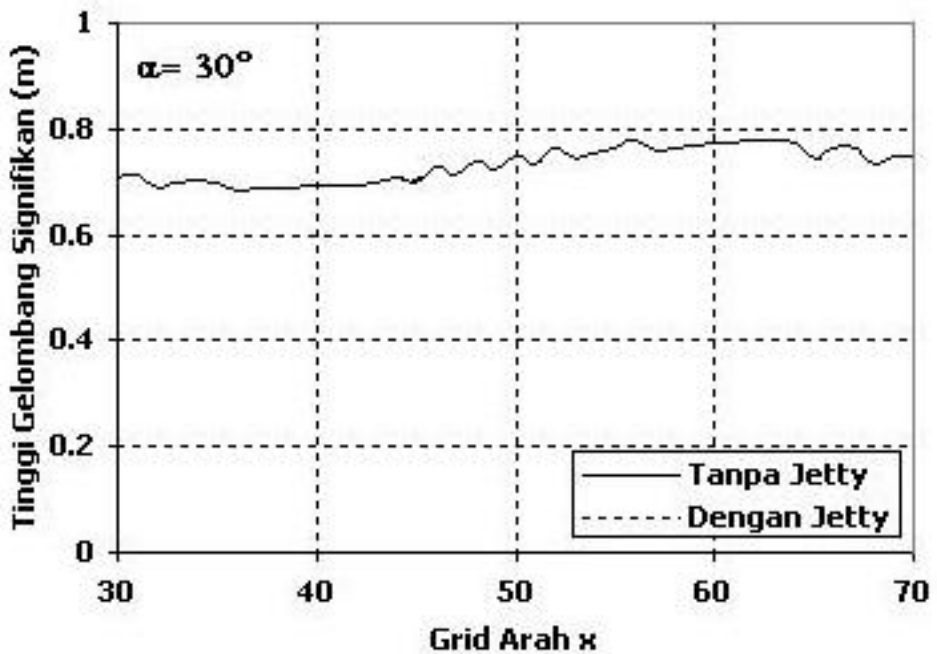

Gambar 14. Perubahan tinggi gelombang di depan jetty pada $\alpha=30^{\circ}$

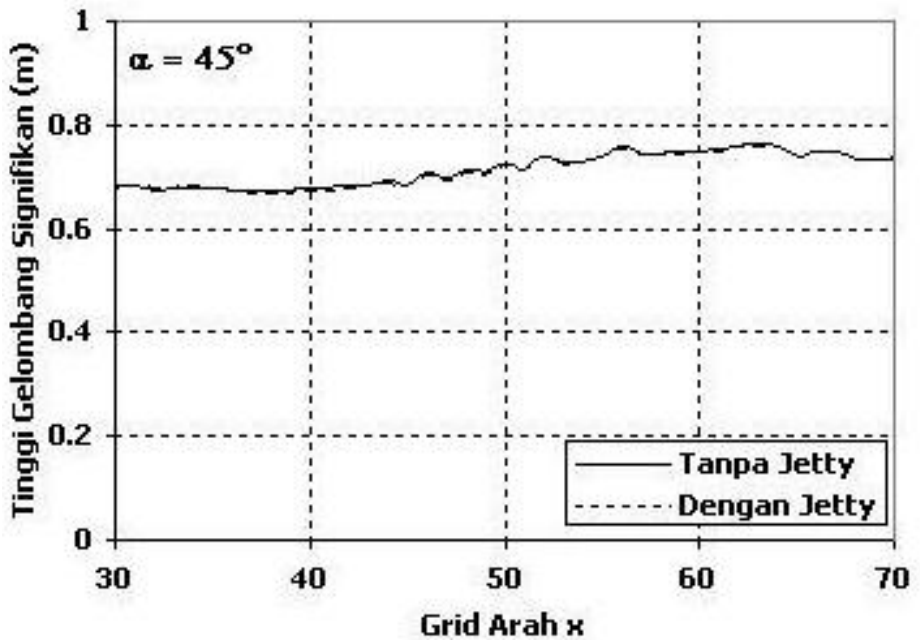

Gambar 15. Perubahan tinggi gelombang di depan jetty pada $\alpha=45^{\circ}$ 


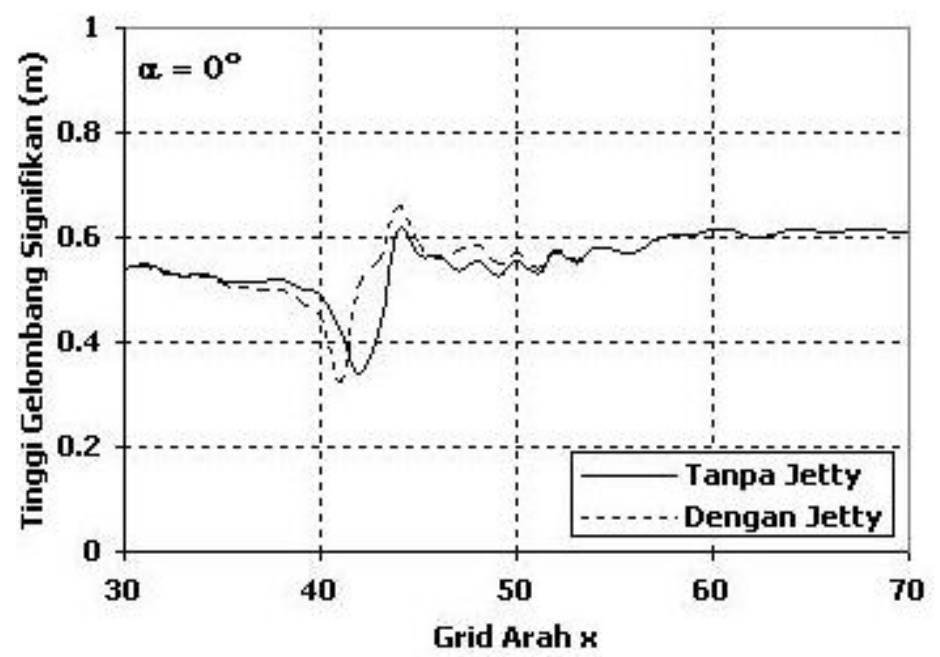

Gambar 16. Perubahan tinggi gelombang di belakang jetty pada $\alpha=0^{\circ}$

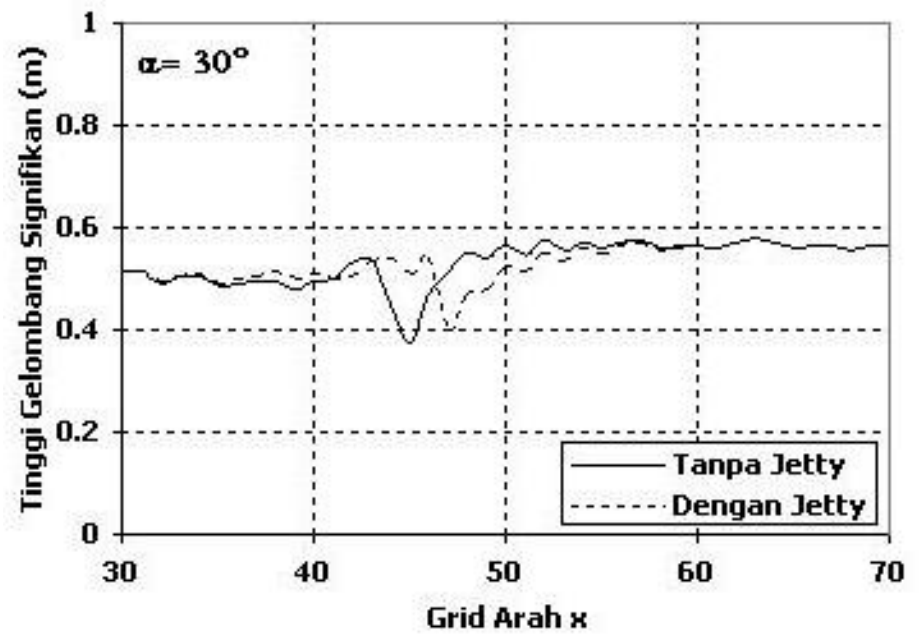

Gambar 17. Perubahan tinggi gelombang di belakang jetty pada $\alpha=30^{\circ}$

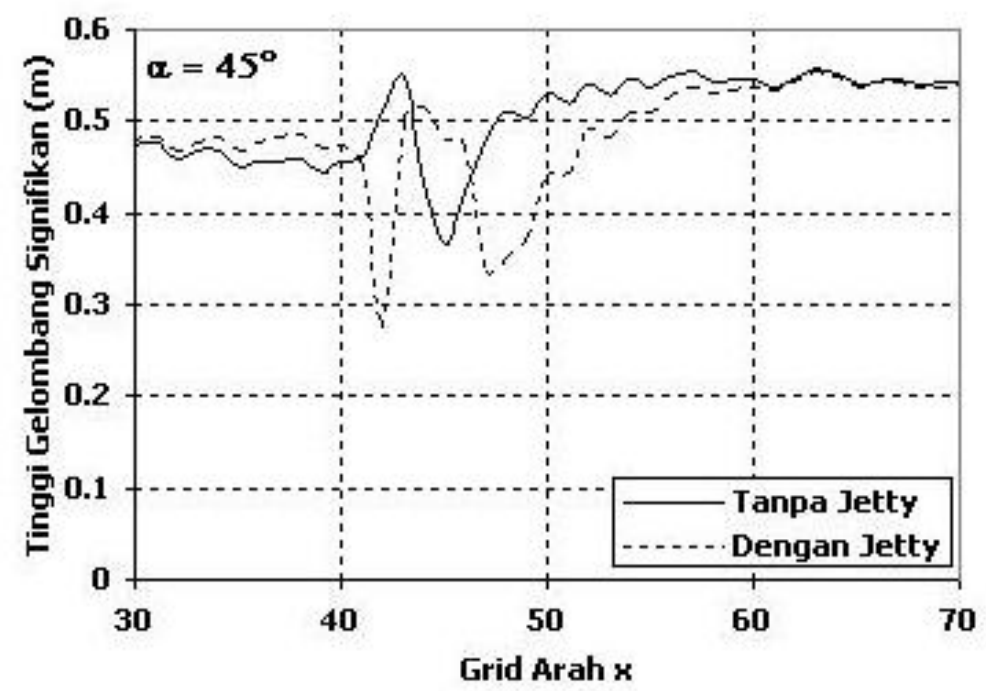

Gambar 18. Perubahan tinggi gelombang di belakang jetty pada $\alpha=45^{\circ}$ 


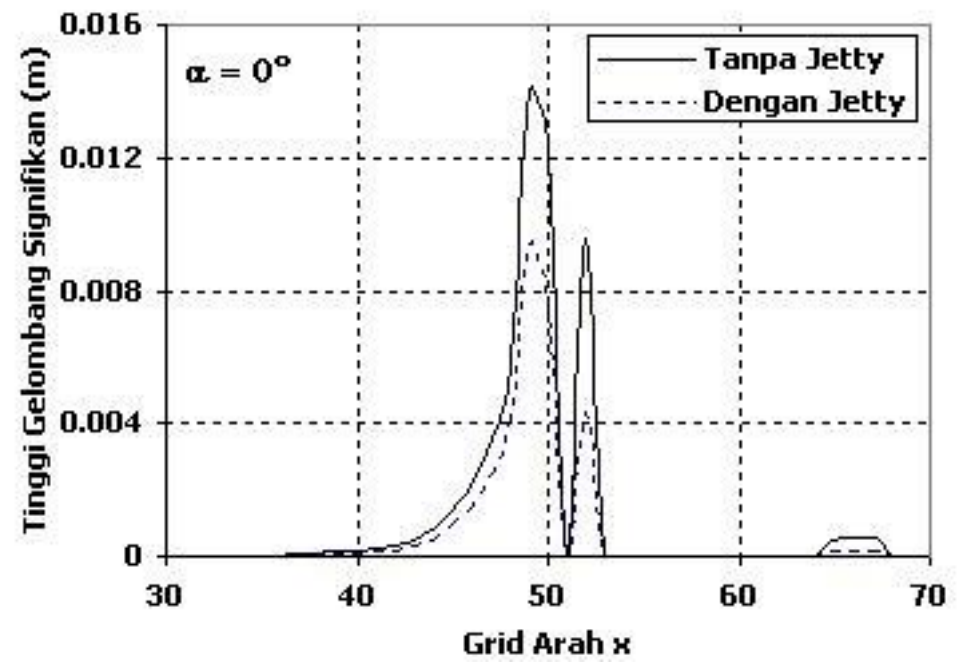

Gambar 19. Perubahan tinggi gelombang di kolam labuh pada $\alpha=0^{\circ}$

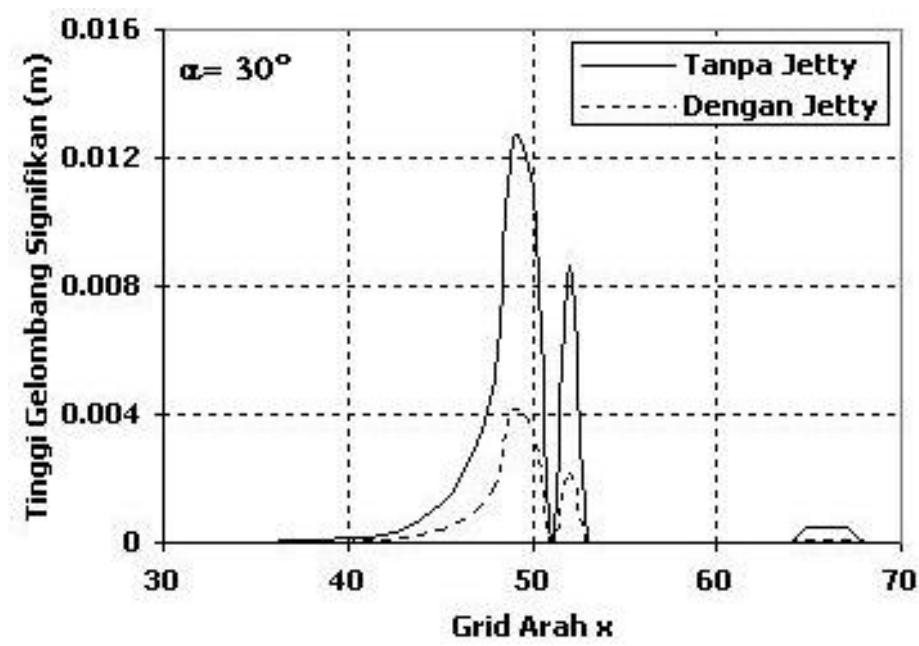

Gambar 20. Perubahan tinggi gelombang di kolam labuh pada $\alpha=30^{\circ}$

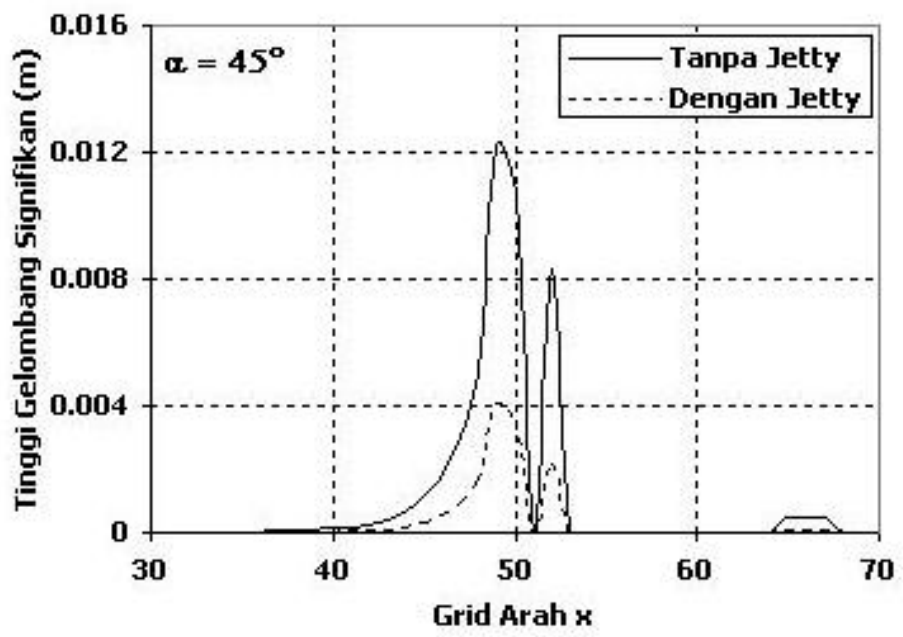

Gambar 21. Perubahan tinggi gelombang di kolam labuh pada $\alpha=45^{\circ}$

\section{KESIMPULAN DAN SARAN}

Berdasarkan pemodelan numerik refraksi gelombang dengan SWAN diberbagai profil pantai dapat disimpulkan sebagai berikut:

1. Pada batimetri dengan kemiringan 0,$01 ; 0,03$ dan 0,05 dan arah gelombang datang $0^{\circ}, 30^{\circ}$ dan $45^{\circ}$ tinggi gelombang akan mengalami perubahan aki- bat refraksi gelombang sebesar 2\%-34\%. Berdasarkan hubungan terjadinya gelombang pecah diketahui bahwa pada arah, tinggi dan periode gelombang sama, maka tinggi gelombang pecah akan semakin besar seiring bertambahnya kemiringan perairan. Hal ini akibat harga $\mathrm{d}_{\mathrm{b}} / \mathrm{H}_{\mathrm{b}}$ semakin kecil yang menunjukkan puncak gelombang semakin curam. 
2. Pengaruh pembangunan jetty di pelabuhan Tegal terhadap perubahan tinggi gelombang yang sangat besar terjadi pada kolam labuh $(228,91 \%)$ dengan arah gelombang $30^{\circ}$, sehingga air kondisinya lebih tenang. Sedangkan pada alur, di belakang jetty dan didepan jetty gelombang mengalami reduksi terbesar $12,96 \% ; 0,02 \%$ dan 3,55\% pada arah gelombang $45^{\circ}$. Pada kondisi didepan jetty gelombang hampir tidak mengalami reduksi karena difraksi dan gelombang pantul tidak berdampak sekitar jarak $70 \mathrm{~m}$ di depan jetty.

3. Penelitian dengan model SWAN ini keakuratannya telah diverifikasi dengan model fisik, namun demikian pada kasus di pelabuhan Tegal ini perlu dilakukan penelitian lebih lanjut dengan pengamatan gelombang secara langsung baik sebelum dan sesudah pembangunan jetty, sehingga pengaruh refleksi dan difraksi akibat jetty dapat diketahui dengan sebenarnya.

\section{DAFTAR PUSTAKA}

[1] Jin, K.R., and Ji, R.G. 1999, "Calibration and Verification of Spectral Wind-Wave Model for Lake Okeechobeei', Ocean Engineering, Vol 28, pp. 571-584.

[2] Andrew, C.J.F. 1999, "Bibliographic Review of nearshore Wave Model", Maritime Operation Division Aeronautical and Maritime Research Laboratory,Melbourne Victoria, Australia.

[3] Kirby, J.T. and Dalrymple, R.A.1983,“A Parabolic Equation For Combined Refrac-tion-Difraction of Stokes by Mild Varying Topography", Journal Fluid Mechanics, Vol. 136, pp. 543-566.

[4] Booij, N, Holthuijsen L.H., and Hernandes., P.R. 1997, "Numerical Wave Propagation On a Curvilinier Grid", Ocean Wave Measurement and Analysis, Vol 1, pp. 286-294

[5] Holthuijsen, L.H., Herman, A., and Booij, N. 2003, "Phase Decoupled Refraction-Difraction for Spectral Wave Model" , Coastal Engineering, Vol 49, pp. 291-305.

[6] Madsen P.A, and Sørensen, R. 1992, 'A new Form of the Boussinesq Equation with Improve Linier Dispersion Characteristics Part 2 a Slowly-Varying Bathimetry", Coastal Engineering, Vol 18, pp. 183-204.

[7] WAMDI Group, 1988, "The WAM Mode a Third Generation Ocean Wave Prediction Model", Phys.Oceanography, Vol 18, pp. $1775-1810$

[8] Battjes, J.A. 2003, 'Development in Coastal Engineering Research', Proceeding of $50^{\text {th }}$ Japanese Conference on Coastal Engineering, pp. 25-39.
[9] Holthuijsen, L.H., Booij, N., Ris, R.C., Haagsma, I.J.G., Kieftenburg, A.T.T.M., Kriezi, E.E., Zijelma, M., and van der Westhyusen, A.J. 2004, "SWAN User Manual Cycle III version 40.31”. Delft University of Technology, Delft.

[10] Holthuijsen, L.H., Booij, N., Ris, R.C., Haagsma, I.J.G., Kieftenburg, A.T.T.M., Kriezi, E.E., Zijelma, M., and van der Westhyusen, A.J. 2004, "SWAN User Manual Cycle III version 40.41”. Delft University of Technology, Delft.

[11] Booij, N, Ris R.C., and Holthuijsen L.H. 1999, "A Third Generation Wave Model for Coastal Region Part 1 model Description and Validation", Geophysics Research, Vol 104, pp.7649-7666.

[12] Mai, S., Ohle, N., and Zimmarmenn, C. 1999. "Applicability of Wave Model in Shallow Coastal Waters", Proceeding of The $5^{\text {th }}$ International COPEDEC, Cape Town, South Africa 1999, Pp. 170-179.

[13] Silva, A.A.P., Makarynsky, O., Monbaliu, J., and Soares, C.V. 2002. "WAM/SWAN Simulation in an Open Coast: Comparison with ACDP Measurement", Littoral 2002 The Changing Coast Eurocoast/EUCC, Porto, Portugal.

[14] Dykes, J.D., Hsu. Y.L., and Rogers, W.E, 2003. "The Development of an Operational SWAN Model for NGLI", Naval Research Laboratory, Missisipi, USA.

[15] Sujantoko, Armono, H.D Dan Novianto, A. 2005, "Verifikasi Model Gelombang Swan Dengan Hasil Eksperimen”, Jurnal Teknologi Kelautan Ftk Its, Nopember.

[16] Gorman, R.M., and Nielson, C.G. 1999, "Modelling Shallow Water Wave Generation and Transformation in An Intertidal Estuary", Coastal Engineering, Vol 36, Pp. 197-217

[17] Chen, Q.J., and Douglas, S.L. 2002, "Characteristic of Ship Wave and Wind Wave in Mobile Bay", Annual Report Summary 4/1/02, Department of Civil Engineering, University of South Alabama.

[18] Schoones, J.S., and Luger, S.A. 2003, "EIA for The Ekspansion of Containment Terminal Stacking Area at The Port of Cape Town", CSIV Report ENV-S-C 2003-83, CSIR Enviromentek,Cape Town.

[19] Park, S., and Park, S.H. 2004, "Operational Wave Forecast and Verification at KMA and New Implementation Planar for The $2^{\text {nd }}$ Phase KMA Superkomputer", Numerical Weather Prediction Division, Korea Meteorological Administration, Seoul.

[20] Edge, B.L. 2004, "Insitu Containment and Treatment: Engineering Cap Integrity and Reactivity”, EPA Project Report, HSRC/S \& Sw, Texas A \& M University.

[21] CERC 1984, "Shore protection Manual", US Army coastal Engineering Research centre, Washington 